\title{
Amerykanin i Polak w Paryżu (Henry James - Bolesław Prus)
}

\author{
Ewa Paczoska
}

(Uniwersytet Warszawski)

Związki twórczości Bolesława Prusa i Henry'ego Jamesa domagają się na pewno poważniejszego rozpoznania. Już formuły, przy pomocy których interpretuje się pisarstwo autora Ztotej czary, kierują wyraźnie ku orbicie Prusa. Jak mówi bowiem Mirosława Buchholtz, wybitna polska znawczyni twórczości tego angielsko-amerykańskiego pisarza, „Henry James to niezapomniany badacz społecznych modeli i relacji płci, meandrów świadomości i psychiki. [...] Jego duchowość i etyka pozbawione religijnego dogmatyzmu, są wskazówką także w obecnych czasach. [...] w jego pisarstwie kryją się całe pokłady humoru, pozwalające spojrzeć na życie jak na farsę czy też komedię omyłek" . Ale Jamesa z Prusem łączy także poszukiwanie realizmu, sposób pytania o możliwości i granice reprezentacji. Myślę, że warto byłoby np. przeczytać razem Notatki o kompozycji i wypowiedzi Jamesa o literaturze (w tym także komentarze do własnych powieści, jak np. wydanej niedawno po polsku The Golden Bowl). Osobnej refleksji wymaga też na pewno obszar wspólnych poszukiwań i odkryć psychologicznych Prusa i brata słynnego wówczas psychologa Williama Jamesa. $Z$ tym ostatnim zaś wiąże się problematyka religijna czy metafizyczna - nawiasem mówiąc, niezrozumiały wydaje się fakt, że uwagi badaczy nie przyciaggnęły dotąd związki Prusa z twórcą pragmatyzmu religijnego, którego dzieła autor Lalki mógł znać.

Moje ambicje w związku z tym artykułem są dużo skromniejsze - chciałabym pokazać tu (zaskakujące czasem) możliwości wspólnej lektury Lalki i jednej z pierwszych powieści Henry'ego Jamesa. Amerykanin, opublikowany w I877 r., to czwarta książka autora należącego do tego samego pokolenia co Prus (urodził się w i843 r.,

1 M. Buchholtz, Henry James isztuka auto/biografii, Toruń 2011, s. 10. 
umarł w I9I6 r.), której zresztą sam nie cenił². Dwukrotnie wracał do tej powieści, by ją ukończyć - raz w I890 r., gdy przerobił ją na sztukę, potem w I905 r., kiedy radykalnie ją zmodyfikował, przygotowując nowojorską edycję swoich utworów. Badacze widzą w tym utworze wpływy Turgieniewa, którego James poznał w Pary$\dot{z} u$, ale przede wszystkim Balzaka. W trakcie pracy nad Amerykaninem James pisze dwa ważne eseje: Honoré de Balzac (I875) oraz Balzac's Letters (1876)33. Rodowód balzakowski ma bez wątpienia wykorzystany tu model „Bildungsroman”, który prowokuje do porównywania losów bohatera Jamesa z dziejami Rastignaca z Ojca Goriot ${ }^{4}$. Model ten jest tu zresztą wykorzystany w tak samo przewrotny sposób jak w Lalce, której bohater pokazywany jest w podobnym momencie życia, co Wokulski.

Ta zbieżność losów bohatera tej powieści z przypadkami Stanisława Wokulskiego uderzyła mnie, kiedy przed kilkoma laty przeczytałam po raz pierwszy Amerykanina. Poprzestawszy na tym spostrzeżeniu nie zauważyłam - jak inni badacze twórczości Prusa - ważnego faktu. Powieść Jamesa, pierwodruk angielski: 1877, ukazała się po polsku już rok później (na karcie tytułowej widnieje data 1878-1879) nakładem znanej lwowskiej księgarni Gubrynowicza i Schmidta5. Prus, zainteresowany, jak wiadomo, kulturą i literaturą angielską, na pewno mógł więc ją czytać - i to niemal dokładnie w tym czasie, gdy życie skierowało go ostatecznie w stronę literatury. Może więc utwór Prusa to swoista odpowiedź na Amerykanina? Żeby to stwierdzić, spróbujmy wskazać związki obu tekstów, skupiając się przede wszystkim na szczegółowej lekturze powieści Jamesa.

Bohaterów obu powieściowych historii łączy bardzo wiele. Po pie rws z e: obaj są "nowymi ludźmi” (na co wskazuje nazwisko Christophera Newmana), ukształtowanymi w warunkach nowoczesności, którzy próbują przebić się w starym świecie społeczeństwa kastowego. Ta cecha wyraźniejsza jest oczywiście u Newmana, ale przecież w podobny sposób postrzegają Wokulskiego przedstawiciele arystokracji. O obu przybyszach snuje się fantastyczne opowieści, odbijające się w wizjach Izabeli i w plotkach opowiadanych w paryskim salonie de Bellegarde'ów (jak np. te, że Newman zbudował milionowe miasto na zachodzie Stanów Zjednoczonych czy że ma szanse zostać prezydentem). Salonowe towarzystwo ma w obu powieściowych światach te same trudności z zaakceptowaniem kupca, rodzina

2 Widać ten dystans choćby w autorskim wstępie do Ztotej czary.

3 Zob. W.W. Stowe, Balzac, James, and the Realistic Novel, Princeton 1983.

4 L. Budrecki, Postowie, w: H. James, Amerykanin, tłum. A. Callier, Wrocław 1998, s. 463. Wszystkie cytaty z powieści na podstawie tego wydania.

5 Spis polskich przekładów Jamesa znajduje się w cytowanej wyżej książce Mirosławy Buchholtz. W czasach Prusa ukazały się także na łamach prasy 2 zbiory opowiadań Jamesa, na inne przekłady trzeba było czekać aż do lat 60 . XX w. Prawdziwa kariera Jamesa w Polsce to jednak dopiero początek XXI w. Choć rację ma Buchholtz, gdy mówi, że „w Polsce Henry James pozostał jedynie młodszym bratem Williama, słynnego filozofa i psychologa", op. cit., s. 11. 
de Bellegarde’ów stwierdza: „Doprawdy sami siebie nie możemy przekonać, aby zaakceptować kogoś trudniącego się handlem” (s.3I9); ostateczne odrzucenie przez arystokratów Newmana pani Tristram tłumaczy w ten sposób, że „przecenili swoją odwagę”. Tomasz Łęcki, zapraszając Wokulskiego, mógłby zapewne powtórzyć za markizem de Bellegarde: „trzeba uczynić jakieś ustępstwo na rzecz nowoczesności” (s. 200). Ustępstwo, dodajmy, równie trudne wobec warszawskiego kupca, jak i wobec Amerykanina, który zrobił pieniądze na handlu skórami i na produkcji balii.

Po drugie: obaj bohaterowie to mężczyźni po przejściach, znajdujący się w szczególnym momencie życia, na progu męskiej „strefy cienia” (choć Christopher jest młodszy od Stanisława ok. Io lat, także ma poczucie, że wiele już przeżył - więcej niż ludzie w jego wieku). Ten okres późnego męskiego dojrzewania mało ma wspólnego z czasem adolescencji (charakterystycznym jako rama „Bildungsroman”), łączy się raczej z przechodzeniem po jungowsku pojmowanej indywiduacji - jest ważnym etapem integracji osobowości, bilansującym niejako doświadczenia młodości i progu dojrzałości.

Po tr z e ci e: obaj są ludźmi sukcesu, którzy zrobili karierę finansową kosztem wyrzeczeń i trudów. Obu nazwać więc można zdobywcami nowoczesnego świata. Newman na pytanie, czy był kiedyś zakochany, odpowiada, że nie, gdyż uczucia wzbudzały w nim wyłącznie „działania” - tak samo odpowiedzieć mógłby Wokulski przed spotkaniem z Izabelą. Obaj byli żołnierzami i obaj wynieśli z tego czasu - Newman z wojny secesyjnej, Wokulski z powstania styczniowego, toczącego się dokładnie w tym samym czasie - poczucie przegranej. I każdy z nich, po swojemu, oczekuje, że teraz, po latach zmagań i trudów, przyjdzie pora na nagrodę losu. Albo jeszcze inaczej - że teraz będą mogli, po okresie walki, zarabiania i zdobywania, zacząć „prawdziwe życie”. Sukces finansowy przyniósł im bowiem jednocześnie apetyt na coś więcej, obaj cierpią na brak celu, z którym mogliby się utożsamić. W tym sensie i Wokulskiego, i Newmana można by nazwać beneficjentami nowoczesnego rozwoju, i z drugiej strony, ofiarami obietnicy nowoczesności. Obiecano im, że ruszą z posad bryłę świata i otrzymają za to, zgodnie z pozytywistycznym paradygmatem, nagrodę w postaci szczęścia i poczucia sensu życia. Trawi ich jednak świadomość braku i melancholia, choć u Christophera ukryta za optymizmem wiecznego zdobywcy - o który bez wątpienia łatwiej było w Ameryce lat 70. XIX wieku niż w postyczniowej Polsce. W siódmej dekadzie XIX wieku obaj bohaterowie rozpoczynają swoją bitwę o spełnienie obietnicy - i obaj ją przegrywają. Uderza ta zbieżność zwycięstw i klęsk w obu tych powieściowych biografiach.

Po c zwa r te: obaj wyrośli w cieniu tego samego męskiego mitu kulturowego XIX wieku - choć w jego odmiennych wariantach - amerykańskim i polskim. Choć każdy z tych wariantów kształtował się w kręgu innych doświadczeń historycznych, podobne są w gruncie rzeczy jego cechy i wewnętrzna dynamika poszczególnych 
aspektów. Romantyczna legenda mężczyzny z amerykańskiego Zachodu (o której żywotności można mówić jeszcze do dzisiaj ${ }^{6}$ ) przypomina bowiem romantyczną legendę Polaka - uczestnika wiecznej irredenty albo kresowego rycerza, toczącego bój z wrogami i naturą. $\mathrm{Na}$ obie te postacie mitycznej opowieści nakłada się w drugiej połowie XIX wieku narracja „cywilizacyjna” czy pozytywistyczna, ta spod znaku Samuela Smilesa, opowiadająca o mężczyźnie-zdobywcy rzeczywistości, odkrywcy, pionierze przemysłu, reformatorze społeczeństwa ${ }^{7}$. Newman „czuje pewność siebie, jeśli chodzi o miejsce w społecznej hierarchii” (s. 217), na pozór mniej pewny tego miejsca Wokulski potrafi jednak demonstrować pogardę dla bywalców salonów.

Po pi ąt e: obaj żyją w nowoczesnym społeczeństwie, w nowoczesnym miejskim życiu postrzeganym jako sfera gry i negocjacji. W Paryżu, do którego obaj przybywają w tym samym czasie, czują się aktorami miejskiego społeczeństwa spektaklu. Christopher i Stanisław mogliby się spotkać nad Sekwaną, na tych samych traktach spacerowych. Obaj są w tym mieście zakochani i obaj żywią wobec niego podobne kompleksy. Dla obu Paryż jest uosobieniem, wspomnianej już wcześniej, obietnicy nowoczesności. Jest też kwintesencją europejskości i tego, co się z nią w ich wyobrażeniach łączy. Paryż Wokulskiego to, jak wiadomo, uosobienie wolności politycznej i intelektualnej, „arka cywilizacji” poświadczająca jej celowość. Paryż Newmana to ogród sztuki i wyższych tradycji kultury. Każdy z bohaterów znajduje więc w tej stolicy ówczesnej Europy to, czego brakuje mu we własnym kraju i własnym, toczącym się gdzie indziej życiu. Prawdziwe życie, do którego aspirują obaj trapieni kompleksem niższości prowincjusza, jest właśnie tutaj. I Christopher, i Stanisław, smakując paryskie uroki, czują się trochę jak barbarzyńcy w ogrodzie (to Wokulski mówi: ,jestem dziki człowiek, ale wydobędzie mnie z tego cywilizacja”!), którzy podziwiając ten nowy wspaniały świat mają jednocześnie poczucie, że oni są skądinąd, że to przestrzeń nie do końca dla nich.

I powieść Prusa, i powieść Jamesa, opowiadając historię nowoczesnego zdobywcy trawionego poczuciem pustki i melancholią, pokazują, że w nowoczesnym świecie nie ma zwycięzców, bo nie ma w nim nic stałego poza pieniędzmi. Obaj bohaterowie tej stałości szukają w miłości do kobiety idealnej - to kolejna, s z ó s ta, zbieżność losów bohaterów tych dwóch powieści. To wizja kobiety-anioła, lampy cywilizacji, zakorzeniona i w kulturze angielskiej (z którą James się przecież utożsamiał), i w kulturze amerykańskiej (żeby wspomnieć choćby Londona czy Curwooda), i oczywiście także polskiej. Kobieta „odpowiednia”, czyli wykształcona, reprezentuje

6 Zob. np. współczesną popularną powieść Elizabeth Gilbert The Last American Man (Ostatni taki Amerykanin, tłum. M. Jabłońska-Majchrzak, Poznań 2011).

7 Zob. mój tekst: Idea czystości i piekto mężczyzn w literaturze drugiej potowy XIX wieku, w: Kobieta i rewolucja obyczajowa. Spoteczno-kulturowe aspekty seksualności. Wiek XIX i XX, red. A. Żarnowska i A. Szwarc, Warszawa 2006. 
wyższe, duchowe wartości kultury, niezbędne do cywilizacyjnej integracji brutalnego świata męskiego zdobywania. Dla obu bohaterów takie właśnie wyobrażenie staje się ramą fantazmatu kulturowego, któremu podporządkowują swoje życie. Przez taki właśnie obraz obaj są, jak myśli Wokulski w Paryżu, „zahipnotyzowani”, uzależnieni. Obydwu, o czym już wspomniano wyżej, trapi melancholia, poczucie duchowej pustki, z której wyzwolić ma kobieta „anioł”, która nada sens ich życiu i dopełni je - także przez sam trud zdobywania.

Projektując udane uwieńczenie życia dzięki małżeństwu z Claire, Newman mówi:

$$
\begin{aligned}
& \text { Po co walczyłem i męczyłem się przez te wszystkie lata? Odniosłem } \\
& \text { sukces w interesach i co teraz mam z nim zrobić? Aby uczynić go } \\
& \text { skończenie doskonałym, muszę ulokować w nim piękną kobietę, tak } \\
& \text { jak stawia się doskonały posąg na uprzednio przygotowanym piede- } \\
& \text { stale. Moja wybranka musi być zarówno dobra, jak i piękna, a także } \\
& \text { mądra. [...] Chciałbym otrzymać, określając dosadnie, najlepszy towar } \\
& \text { na rynku (s. 48). }
\end{aligned}
$$

Ta ostatnia deklaracja, formułowana wobec pani Tristram nie przeszkadza jej widzieć w nim bohatera „francuskich poetów romantycznych” (s. 49). Wymagania Newmana wobec przyszłej żony są jasno określone - musi ona być ideałem, na który składają się: „dobroć, uroda, inteligencja, elegancja”, ale i „pozycja” (s. I44). Claire spełnia te wszystkie oczekiwania: "Jedyny kłopot polegał na tym, że gdy instrument jest zbyt doskonały, staje między geniuszem i osobą, która go używa" (s. I5I). Można by powiedzieć, że Newman - w gruncie rzeczy podobnie jak poszukujący ideału Wokulski (który nie określa go jednak z tak brutalną szczerością) - chce otrzymać "produkt” najlepszy na rynku, bo na to zasługuje, a jednocześnie tęskni za aniołem, który pozwoli zapomnieć o regułach wymiany towarowo-pieniężnej. „Chciałbym wszystko załatwić w dobrym stylu. Nie chcę popełnić błędu i gorąco pragnę odnieść pełny sukces. Muszę dokonać właściwego wyboru. Moja żona musi być kimś naprawdę wspaniałym" (s. 47).

Warto w tym miejscu przypomnieć moment, gdy Claire zdaje się najpełniej ucieleśniać ten doskonały ideał: „Miała na sobie białą suknię, a długi, błękitny płaszcz sięgający stóp spięła na ramionach srebrną klamrą. Zsunęła go na plecy, odsłaniając blade ramiona. W jej gęstych włosach błyszczało dwanaście brylantów." (s. 77). W oczach Newmana bohaterka (tak samo jak, również ubrana na biało, Izabela widziana po raz pierwszy w teatrze przez Wokulskiego) jest uosobieniem doskonałości, której poszukuje - robi wrażenie zrobionej z innej gliny, przybyszki $\mathrm{z}$ innego świata. Zupełnie inaczej postrzega Claire np. pani Tristram, co jest być może wyrazem kompleksów tej ostatniej wobec paryskiego towarzystwa, jak mówi: 
„madame de Cintré to wielka blada lala, kultywująca oziębłą wyniosłość” (s. 53). Podobnie banalność i zwyczajność panny na wydaniu wskazują ci, którzy krytykują w Lalce przedmiot zalotów Wokulskiego.

Gdy Newman poznaje bliżej Claire, czuje się ,jak ktoś, kto w czasie wspinaczki nie znalazł oparcia dla stopy tam, gdzie spodziewał się je znaleźć" (s. Io5). Wcześniej - znów podobnie jak Wokulskiemu - utrwalił mu się „wyraz dwojga oczu - równocześnie błyszczących i łagodnie przymglonych” (s. 8o). Czuje się zaniepokojony i onieśmielony: „Kim była za sceną - było tajemnicą - i to właśnie najbardziej frapowało Newmana" (s. 132). Inaczej niż w przypadku Izabeli Łęckiej w Lalce, czytelnik nie wie o Claire prawie nic, narrator nie zdradza się z żadną dodatkową wiedzą na jej temat, ogranicza się tylko do prezentowania jej z perspektywy Newmana. Pogłębia to wrażenie tajemnicy - nie samej bohaterki, lecz wyborów Christophera skupionych wokół budowania „twardego”, wyrazistego fantazmatu.

Przyjaźń czy zażyłość Newmana z bratem Claire rodzi się wówczas, gdy Vincent w rozmowie o siostrze przedstawia ją jako wcielenie ideału, jakby dostarczając dodatkowych argumentów o oczekiwanej doskonałości: „w połowie grande dame, w połowie anioł; mieszanina dumy i pokory, orlica i gołębica. Przypomina posąg, który przestał być kamieniem, wyzbył się poważnych błędów kamienia, stając się żyjącym ciałem, w którym płynie krew" (s. I35-136). Wypowiedź ta buduje obraz jednorodny i kompletny, na co składają się także informacje o tym, że Claire jest ofiarą rodziny, wobec której posłuszeństwo wiąże ją ,jak religia” (s. 358).

Vincent określa siostrę jako „zimną" - ta cecha (podobnie jak w przypadku „posągowej” Izabeli) zdaje się szczególnie przyciągać jej wielbiciela. Wyobrażenie obu wybranek nosi znamiona kulturowego fantazmatu, który wydaje się w jakimś stopniu abstrahować od konkretnych cech jego nosicielek, zamieniając się w swoisty fetysz. Fantazmat ten w powieści Jamesa, tak samo jak u Prusa, budowany jest poza sferą pragnienia seksualnego. Newman po rozmowie $z$ Vincentem „w myślach odrzucał pogląd Francuza, który odkrywał jakiś pożytek w uprawianiu seksu, czego zresztą u siebie nie podejrzewał." (s. I29). Nie przeżywa też ekscytacji uczuciowej: „nie odkrył w sobie żadnych przypływów lub odpływów romantycznej namiętności. [...] Czuł gorącą, wszechogarniającą go tkliwość [...] ku obiektowi” (s. 2I2). „Newman był po prostu oczarowany i traktowal to oczarowanie jak dźwięk pozytywki, która może przestać grać, gdy ją ktoś poruszy. Nie mogła istnieć doskonalsza próba pragnienia epikurejczyka - coś, co kryje się w każdym człowieku - czekającego na niespodziany sygnał od jakiegoś boskiego sprzymierzeńca. [...] zwieńczony różami starożytny Grek wpatrujący się w boginię z marmuru i całym swym intelektem cieszący się z doskonałości dzieła, nie mógł- 
by być doskonalszym ucieleśnieniem mądrości zatraconej w rozkoszowaniu się spokojem harmonii”(s. 2I3). Oświadczając się Claire, Christopher nie mówi nic o swoich uczuciach, wyraźnie upodrzędnia jednak erotyczną ramę tej relacji: „Ze mną [...] będzie pani bezpieczna [...] jak można się czuć bezpieczną [...] w ramionach ojca” (s. 234). Rację ma młoda markiza de Bellegarde, która stwierdza, że Christopher wybrał madame de Cintré „jak jakieś zrodzone z wyobraźni stworzenie lub przedmiot" (s. 272). Wybrał obiekt pragnienia - gdy na przyjęciu cieszy się, że „otrzymał to, czego pragnął” (s. 279), nie zdaje sobie sprawy, ze osiągnięcie tak określanego celu jest równoznaczne $\mathrm{z}$ jego utratą.

I Newmanowi, i Wokulskiemu, religia kojarzy się ze sprawą dawno przebrzmiałą, nie mającą nic wspólnego ze sferą ich doświadczeń czy w ogóle z nowoczesnym światem. Jednocześnie, co wynika z moich wcześniejszych rozpoznań, trawi ich tęsknota za czymś, co doskonałe i wyższe - nostalgia charakterystyczna dla świata odczarowanego, w którym wygaszono „święte ognie”. Bohater Jamesa, zanim pozna Claire - która stanie się figurą tej tęsknoty - próbuje nawiązać romans z Europą jako matecznikiem wartości duchowych: „chcę się czegoś dowiedzieć o Europie. Czuję tu, pod żebrami [...] coś, czego nie potrafię określić... jakąś przemożną tęsknotę sięgnięcia po to i wchłonięcia tego w siebie" (s. 44). To niezaspokojona potrzeba przeżyć o charakterze metafizycznym kieruje Newmana w stronę miłosnego fantazmatu. Ten sam mechanizm widać w losach Wokulskiego: tu nierealizowalna po powrocie z Syberii metafizyczna miłość do ojczyzny czy postromantyczna religia polskości każe mu szukać obiektu „wyższego”, z którego można uczynić cel życia (cel, dla którego alternatywą jest przecież w rozmyślaniach Stanisława - śmierć!).

O podobnym zjawisku Mircea Eliade pisał: „nieustająca desakralizacja człowieka współczesnego wypaczyła treść jego życia duchowego nie niszcząc jednak wzorów jego wyobraźni; w strefach wymykających się kontroli trwa i żyje cała zdegradowana mitologia”" . Potrzeba przeżywania archetypów, potrzeba widzenia swego życia w porządku mitycznym, w odczarowanym świecie nowoczesnym, niemożliwa z różnych względów do zaspokojenia (oczywiście poza wyspecjalizowanymi instytucjami, jak np. kościół), przybiera postaci zbanalizowane i płaskie, których wylęgarnią staje się, o czym wspominał Eliade, kultura popularna.

Wyobrażenie kobiety-anioła, fantazmat, za którym gonią bohaterowie obu powieści, tyleż bowiem zawdzięczać może wzniosłym tęsknotom poszukiwaczy ideału, co - pragnieniom kształtowanym przez kulturę popularną, np. przez dziewiętnastowieczny melodramat. W bohaterze Amerykanina uderza zwłaszcza to, że

8 M.Eliade, Sacrum, mit, historia: wybór esejórw, wybór M. Czerwiński, tłum. A. Tatarkiewicz, Warszawa 1970, s. 31. 
fascynując się sztuką i kulturą wyższą, którą uosabia dlań Europa, tak naprawdę jest on tylko doskonałym konsumentem ${ }^{9}$. Oczekując wkroczenia w swoje życie wartości duchowych, przykrawa je do poziomu zwykłego zjadacza kultury, np. czytelnika tak modnych wówczas popularnych romansów. A może to i one, oprócz „zbójeckich” lektur jego młodości, ukształtowały wyobraźnię Wokulskiego? - widać to wyraźnie np. w tym momencie, gdy bohater planuje przyszłe życie z wybranką w majątku, który chce nazwać Izabelinem. To marzenie więcej ma wspólnego z horyzontami mieszczańskiej kultury popularnej niż z wyobrażeniami kochanka Maryli o tkliwym związku dusz.

Warto w tym miejscu przypomnieć zaproponowane przez René Girarda analizy „pragnienia trójkątnego” w powieściach Stendhala, Flauberta czy Zoli. Bowaryzm traktuje Girard jako „wypaczenie potrzeby transcendencji”, a nowoczesnych konsumentów nazywa „ofiarami współczesnej ewangelii”. Podobnie można by zakwalifikować przypadek Newmana i Wokulskiego, bohaterów mających podstawowe kłopoty z tożsamością i oczekujących, że dopiero wejście w posiadanie obiektu pragnienia pozwoli ją odzyskać czy na nowo zbudować. Izabela i Claire pełniłyby tutaj zatem rolę pośredniczącego Innego.

\section{》Bohater zwraca się namiętnie ku Innemu, który zdaje się boskim dziedzicem. Wiara ucznia jest tak wielka, że czuje się bliski odebrania pośrednikowi jego duchowej tajemnicy. [...] Odwraca się od teraź- niejszości i żyje w promiennej przyszłości ${ }^{\mathrm{TO}}$.}

Jak pisze Girard, analizując fantazmaty postaci zaludniających strony powieści Flauberta, „wyobraźnia bohatera jest matką złudzenia, ale temu dziecku potrzebny jest jeszcze ojciec i ojcem tym będzie pośrednik"I . Próby realizacji fantazmatu, którym coraz bardziej gorączkowo oddają się w toku powieści Newman i Wokulski, kierują ich w stronę produktów zastępczych i specyficznych konstrukcji myślowych. I tak w wyobrażeniach Wokulskiego, tuż za Izabelą postępuje Maria „magdalenka”. Obecność tego „zwierzęcia”, jak nazywa ją bohater, daje dziwaczną gwarancję zaistnienia „kobiety-anioła”. Podobną dziwaczną parę tworzą bohaterki Amerykanina: Claire i Noemi. Obraz kobiety idealnej uzupełnia, jako rewers, obraz kobiety upadłej. U Jamesa motyw obrazu pełni ważną rolę w fabule. Wprowadza

9 O konsumenckim podróżowaniu Newmana po Europie piszę więcej w szkicu Koniec podróży? (E. Paczoska, Prawdziwy koniec XIX wieku. Śladami nowoczesności, Warszawa 2010, s. 120).

10 R. Girard, Prawda powieściowa i ktamstwo romantyczne, tlum. K. Kot, Warszawa 2001, s. 64. Zob. także: D.M. Fogel, Henry James and the Structure of the Romantic Imagination, Baston Rouge 1981.

11 R. Girard, op. cit., s. 28. 
go postać Noemi Nioche, która kopiuje obrazy w Luwrze, ale tak naprawdę sama prezentuje się jako obraz (kopia) do nabycia. Takiego nabywcę widzi w Newmanie, któremu najpierw sprzedaje „piękną Madonnę”, pokrytą grubą warstwą werniksu i w bogatej złoconej ramie. Pośredniczący w tej transakcji ojciec pełni rolę stręczyciela i jednocześnie uczy Newmana francuskiego. Te lekcje i obrazy mają stworzyć okazję do sprzedaży ciała. Kiedy Newman zamawia kolejne kopie u Noemi (powodowany współczuciem dla jej ojca) ona wybiera same dzieła związane z tematyką relacji damsko-męskich (jak np. Ślub Marii Magdaleny Rubensa). Gdy Newman nie odczytuje tych sygnałów, Noemi przemawia jawnym tekstem: przyznaje, że nie umie malować, a rola kopistki służy tylko znalezieniu bogatego opiekuna. W oczach Newmana mademoiselle Nioche ujednoznacznia się w końcu jako kiepska kopia „kobiety idealnej”, malowidło, mimo bogatych ram, tandetne, nieudolnie naśladujące oryginał. W opozycji do Noemi - Claire jest towarem pierwszego gatunku, obrazem o nie podrabianej autentyczności, atrakcyjnym przez swą „doskonałość” i niedostępność, można by rzec - z certyfikatem najwyższej jakości. Sprawa ideału i kopii powraca także, choć mniej jawnie, w Lalce - nie tylko w scenach z „magdalenką”, ale w tych wszystkich momentach, gdy Wokulski porównuje z Izabelą kolejne kobiety (pani Wąsowska, Ewelina, słuchaczki koncertu Molinariego). Zarówno kobiety „zwierzęce” czy „towarowe”, jak i te ,anielskie” niepokoją obu bohaterów możliwością zamiany ról - grożącej unieważnieniem czy destrukcją fantazmatu „doskonałości”.

Mówiąc o specyfice zarysowanego w obu utworach fantazmatu kobiecości, trzeba też podkreślić charakterystyczną „lalkowatość” obu obiektów pragnienia ${ }^{\mathrm{I2}}$. I francuska potomkini markizów, i warszawska zubożała arystokratka to nie tylko lalki salonowe, lecz przede wszystkim kukiełki z męskiego teatru wyobraźni, jednakowo wyraziste w swojej specyficznej bezcielesności, nieobecności. Amerykański przyjaciel Newmana próbując odwieść bohatera od decyzji ożenku z Claire, mówi (w przekładzie dziewiętnastowiecznym), że to „lalka obdarzona olbrzymim zasobem pychy” (w oryginale „doll liked woman”, kobieta-lalka lub lalka przypominająca kobietę). Kiedy rodzina Claire doprowadza do zerwania jej zaręczyn z Newmanem, Tristram komentuje, że może dobrze się stało, bo po zaślubieniu wybranki jego przyjaciel znalazłby się „w czymś, co przypomina zamkniętą skrzynię. Możesz być przekonany, że z czasem [Claire] stałaby się sztywna i - daję słowo - nie widzę

12 W twórczości Jamesa motyw kobiety-lalki powraca wiele razy, szczególnie wyraziście w The Golden Bowl z 1904 r. Maggie, bohaterkę tej powieści, w scenie na przyjęciu goście w salonie przekazywali „sobie ostrożnie z rąk do rąk niczym wystrojoną lalkę, trzymaną tak jak należy za starannie wypchany tułów. Może zamierzali wymusić z niej odpowiedź, naciskając na jej brzuch, może spodziewali się, że powie głosem idealnie wręcz naśladującym ludzki: «o tak, jestem tu przez cały czas, ja, solidnie wykonane cacko; kosztowałam mojego ojca całkiem sporą sumkę»" (H. James, Ztota czara, tłum. A. Kłosiewicz, Warszawa 2011, s. 439). 
cię w roli szczęśliwego małżonka u jej boku" (s. 436). Tristram w tym momencie nie zdaje sobie sprawy, że na tym właśnie zależało Christopherowi najbardziej: chciał ulokować lalkę w zamkniętej przestrzeni swojej wyobraźni jak na scence ulicznego kukiełkowego teatrzyku, odciętej od powszedniości, ale i od rzeczywistości. Podobnie Wokulski zamyka Izabelę w swoich rojeniach - nie przypadkiem brutalnie przerywa je scena $\mathrm{w}$ pociągu, związana wszak organicznie $\mathrm{z}$ otwieraniem przestrzeni czy naruszaniem jej granic!

Kiedy rodzina de Bellegarde'ów ostatecznie odmawia ręki Claire Newmanowi jako niegodnemu jej amerykańskiemu handlarzowi, a ta (znów podobnie jak Izabela, choć na dłużej) zamyka się w klasztorze, bohater Jamesa z jednej strony traci swój fantazmat, $z$ drugiej jednak, paradoksalnie, go zachowuje. Epilog powieści rozgrywa się w duchu melodramatu (do którego James miał zresztą skłonności). Mam tu na myśli wątek pani Bread, starej służącej, która sprzedaje Christopherowi rodzinne tajemnice. W jej opowieści jest cały repertuar rozwiązań charakterystycznych dla melodramatu: spisek, niewinna ofiara, ukryta prawda. Czym staje się ta opowieść i zaangażowanie w nią dla Newmana? Pozwala mu wcielić się w postać szlachetnego obrońcy, niejako wyjść z całej tej historii z twarzą. Dzięki temu może dalej zachować swój ideał. Nie zdobył doskonałego obiektu pragnienia, ale zachowuje chociaż swoją szlachetność - i może snuć dalej narrację o moralnym zwycięstwie, jakby wyjętą z fabul modnych sztuk teatralnych, które mógł wówczas oglądać w Paryżu: L'étrangère Dumasa-syna czy La petite comtesse Feuilleta ${ }^{\mathrm{I}}$.

W Stanach Zjednoczonych do dziś mawia się, że dobrzy Amerykanie po śmierci idą do... Paryża, by tam delektować się swoim ulubionym mitem popkultury. Również Paryż Newmana realizuje jakoś tę mityczną obietnicę. Claire pozostaje zamknięta w klasztorze, a bohater stabilizuje się w roli „szlachetnego odrzuconego”, do końca wiernego swojej miłości. Inaczej dzieje się w przypadku Wokulskiego - bo jego „idol” okazał się obiektem trudniej poddającym się wyobrażeniowym operacjom. Miał udźwignąć wszak ciężar rojeń jednostkowych i, w pewnym sensie, zbiorowego marzenia o ideale, któremu można poświęcić swoje życie. Historia bohatera Lalki nie kończy się, jak ta Newmana, w realiach popkultury - choć także się o nią ociera, np. w scenie seansu paryskiego hipnotyzera. A może też w scenie z charakterystycznym „żywym obrazem” - alegorią Sławy w warszawskich Łazienkach? Wokulski nie odchodzi, jak Newman, w stronę melodramatu - wybiera strukturę całkiem innej, polskiej opowieści, podporządkowanej odmiennemu obiektowi pragnienia, o czym pisałam już w mojej książce o powieści Prusa. W jednej z wersji

13 Na związki z tą popularną literaturą francuską wskazuje Lech Budrecki, który pisze o „niedwuznacznych upodobaniach Henry'ego Jamesa do prozy opartej na wzorach melodramatu" (L. Budrecki, Postorwie, op. cit., s. 463). 
zakończenia Wokulski miał przecież wyruszyć znów do Paryża, aby spotkać się z kolejnym fantazmatem.

I Amerykanin, i Lalka to nie tylko powieści o przegranych zdobywcach, lecz przede wszystkim - o zagubionych mężczyznach, próbujących, mówiąc w dużym skrócie, uzgodnić ikonę z idolem. Albo raczej: uciec od niepokojących ich realiów wymiany towarowo-pieniężnej w stronę idealistycznych wyobrażeń - czy to spod znaku Byrona, czy spod znaku Smilesa. Ciekawym rozwinięciem tego wątku jest relacja Newmana i młodego de Bellegarde'a, w pewnym sensie analogiczna do relacji: Wokulski - Ochocki. Obu młodszych mężczyzn tak samo fascynują zdobycze ich starszych kolegów. Obaj zazdroszczą tamtym wiary, która pozwoliła im odnieść sukces. Valentin, podobnie jak Ochocki, ma bowiem uczucie, że w momencie jego wejścia w dorosłość wszystkie karty zostały już rozdane, a jego pokoleniu pozostał już tylko jakiś wybrakowany świat „post”, w którym pozostaje grać z góry wyznaczone role albo kolekcjonować wrażenia. Młody de Bellegarde sam określa się jako „człowiek przegrany” $\mathrm{i}$ zupełne przeciwieństwo Christophera, człowieka sukcesu (pierwszą poważną rozmowę obu mężczyzn porównać można zresztą do dialogu Wokulskiego z Ochockim w warszawskim Ogrodzie Botanicznym). Czytelnik powieści Jamesa i Prusa wie jednak, że również zdobywcy są zmęczeni, że także oni poszukują celu, by nadać sens swojemu życiu.

Valentin swój brak szans łączy z europejskim wyczerpaniem, które rozpoznaje także przybysz z Ameryki: „Newman zauważył, że w Ameryce dwudziestopięcio-, trzydziestoletni mężczyźni mają głowy ludzi starych, ale młode serca, a już z całą pewnością hołdują młodzieńczym zasadom moralnym; tu zaś mają młodzieńcze głowy, bardzo stare serca, a ich moralność posiwiała i pokryła się zmarszczkami” (s. I23). Valentina, podobnie jak Ochockiego, toczy robak melancholii, zazdrości Amerykaninowi tego, że od zakończenia wojny kierował się imperatywem zdobywcy, że, tak samo jak Wokulski, musiał się wspinać: „Znajdował się pan w sytuacji, której każdy mógł panu pozazdrościć [...] Kiedy ja miałem dwadzieścia lat, rozejrzałem się i widziałem świat opatrzony etykietką «nie dotykaj!»” (s. I24). Melancholik i kolekcjoner wrażeń nigdzie nie czuje się u siebie ${ }^{\mathrm{I4}}$, stąd na Newmanie robi wrażenie „nie zainwestowanego kapitału” (s. 298), który trzeba wprawić w ruch, natchnąć jakimś celem.

Śmierć Valentina w wyniku pojedynku - widzianego tu przez Jamesa tak samo jak w Lalce jako dysfunkcjonalny, absurdalny rytuał („najgorszy sposób zlikwidowania męskich spraw, jak można sobie wyobrazić" - s. 339) - przypieczętowuje rozpoznanie sytuacji człowieka zbytecznego. Sam, umierając, powie: „Społeczeństwo nie straci

14 Tego też zazdrości Newmanowi: „Pan czuje się wszędzie na świecie, jak u siebie w domu” - „pan sam [...] musiał znaleźć swoje miejsce” (s. 126). 
mniej wartościowego członka" (s. 338). I Vincentowi, i Julianowi pozostają tylko dysfunkcjonalne i anachroniczne wzorce tożsamości - albo rola wiecznych chłopców (tego ostatniego w takiej właśnie roli Piotrusia Pana widzimy w Zasławiu). Jakub Malik w swojej interpretacji powieści Prusa trafnie rozpoznaje w Ochockim dekadenta i nerwowca, zauważając, że jego postać wprowadza w „światy Lalki” ważną refleksję o nowoczesności ${ }^{\mathrm{I}}$. To samo można by powiedzieć o młodym bohaterze Amerykanina.

Podsumowując te rozpoznania, warto na koniec powtórzyć pytanie, które postawiłam na początku. Czy Lalka została napisana w dialogu z powieścią Jamesa? Nie można na to pytanie odpowiedzieć jednoznacznie twierdząco. Można jednak domniemywać, że lektura Jamesa stała się dla Prusa jednym z tych przypadkowych (choć w istocie - nieprzypadkowych) zworników jego obserwacji i refleksji o świecie, o których mówi choćby w Stórwku o krytyce pozytywnej. Nie możemy wykluczyć i takiej możliwości, że to właśnie za sprawą Amerykanina planowana powieść o polskich idealistach mogła skleić się w całość.

Lalka czytana razem z Amerykaninem to nie tylko opowieść o losach trzech pokoleń polskich idealistów, ale także o dylematach i pułapkach idealizmu w ogóle. W świecie dotkniętym nowoczesną zmianą romantyczny z ducha (ale i romansowy, na wzór marzeń pani Bovary) idealizm buduje anachroniczne i dysfunkcjonalne fantazmaty, które nie pozwalają swoim wyznawcom na prawdziwy rozwój, blokują ich energię, wreszcie - nie pozwalają ujawnić się instynktom i uczuciom. Wszystkie inne fundamenty - z miłością na czele - okazują się iluzoryczne. Tradycja, którą bohaterowie pragnęliby uszanować w swoich wybrankach, okazuje się tylko krępującym gorsetem form. Niezwykłość Izabeli i Claire to fantazmat, sztuczny produkt, niezbędny dla wytworzenia iluzji pewności.

Obie powieści na pewno rozpoznają naturę nowoczesnego pragnienia ujętą w ramę rzeczywistości kulturowej drugiej połowy XIX wieku, gdy, jak pisał René Girard analizując Madame Bovary, okazało się, że odtąd „ludzie będą dla siebie bogami" ${ }^{\prime \prime}$.

\section{Bibliografia:}

Buchholtz M., Henry James i sztuka auto/biografii, Toruń 2011;

Budrecki L., Postowie, w: H. James, Amerykanin, tłum. A. Callier, Wrocław 1998;

M. Eliade, Sacrum, mit, historia: wybór esejórw, wyb. M. Czerwiński, tłum. A. Tatarkiewicz, Warszawa 1970; Fogel D.M., Henry James and the Structure of the Romantic Imagination, Baton Rouge 1981;

15 J.A. Malik, „Lalka”. Historie z różnych światów, Lublin 2005, rozdz. III Ochocki albo Entuzjazm $i$ zblazowanie.

Zob. R. Girard, op. cit., rozdz. II: Ludzie będa dla siebie bogami. 
Gilbert E., Ostatni taki Amerykanin, tłum. M. Jabłońska-Majchrzak, Poznań 2011;

Girard R., Prawda powieściowa i kłamstwo romantyczne, thum. K. Kot, Warszawa 2001;

James H., Amerykanin, ttum. A. Callier, Katowice 1998;

James H., Ztota czara, tłum. A. Kłosiewicz, Warszawa 2011;

Malik J.A., „Lalka”. Historie z różnych światów, Lublin 2005, rozdz. Ochocki albo Entuzjazm i zblazowanie; Paczoska E., Idea czystości i piekto mężczyzn w literaturze drugiej potowy XIX wieku, w: Kobieta i rewolucja obyczajowa. Spoteczno-kulturowe aspekty seksualności. Wiek XIX i XX, red. A. Żarnowska i A. Szwarc, Warszawa 2006;

Paczoska E., Koniec podróży?, w: eadem, Prawdziruy koniec XIX wieku. Śladami nowoczesności, Warszawa 2010;

Stowe W.W., Balzac, James and the Realistic Novel, Princeton 1983.

SŁOWA KLucze: nowoczesność, fantazmat, idealizm, mit kulturowy, pragnienie

\section{Ewa Paczoska}

\section{An American and a Pole in Paris (Henry James - Boleseaw Prus)}

The article proposes a comparative reading of two novels: American of Henry James and The Doll of Bolesław Prus. The author argues that James' novel published in Polish in 1878 could become an inspiration for Prus. The circle of problems of American and The Doll is focused around similar themes: the identity of a modern man and the patterns of masculinity and femininity. Both novelists show a mechanism of creation for idealistic fantasies.

KEY words: modernity, phantasm, idealism, cultural myth, desire 